ppi $201502 Z U 4645$

Esta publicación científica en formato digital es continuidad de la revista impresa ISSN-Versión Impresa 0798-1406 / ISSN-Versión on line 2542-3185Depósito legal pp $197402 Z$ U34

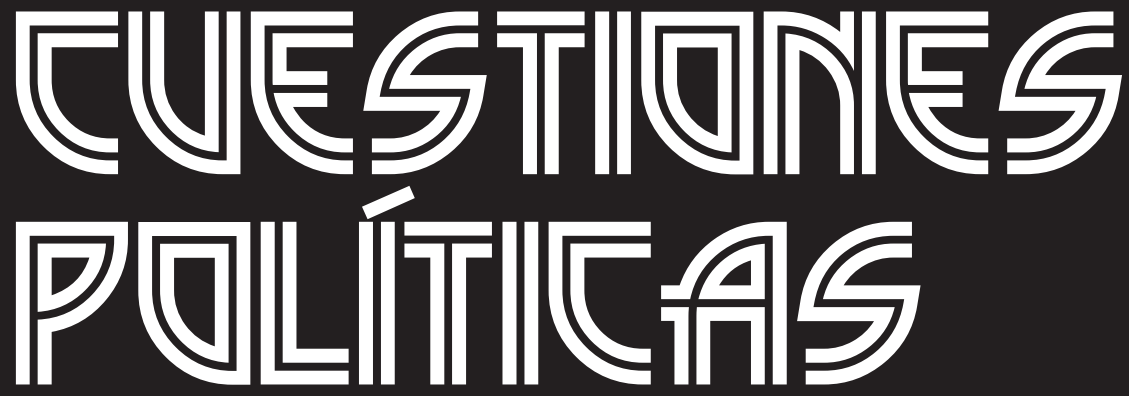

Instituto de Estudios Políticos y Derecho Público "Dr. Humberto J. La Roche" de la Facultad de Ciencias Jurídicas y Políticas de la Universidad del Zulia Maracaibo, Venezuela
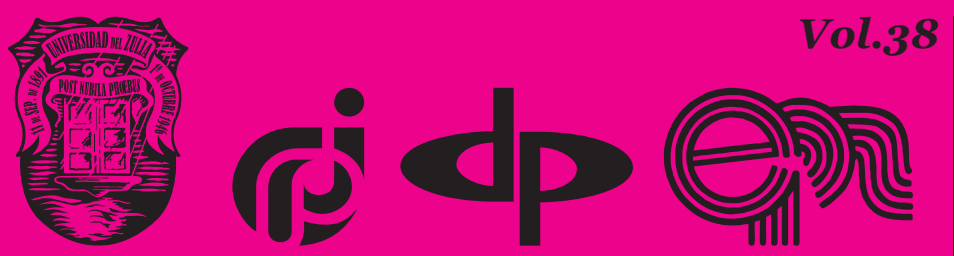

$N^{\circ}$ Especial 1era Parte 2020 


\title{
National identity in an emerging information society: some problematic issues
}

\author{
DOI: https://doi.org/10.46398/cuestpol.38e.o5
}

\author{
Mychailo $V$. Kostytsky * \\ Nataliia V. Kushakova-Kostytska ** \\ Oleg I. Gvozdik *** \\ Vitalii M. Kravets **** \\ Kostiantyn V. Shkarupa $* * * *$
}

Abstract

The objective of the article is to characterize the national identity in an emerging information society. The multidimensionality, internal contradictions, and variability of the phenomenon of national identity led to methodological pluralism, the application of various methods and principles. Thus, during the research, historical and philosophical, dialectical, phenomenological, and systemic approaches, structural and functional methods were used. The article considers the problems related to the development of the information society and the preservation of national identity, including the peculiarities of this process in modern Ukrainian society. The development factors of the information society that influence national and individual consciousness and promote their optimal interaction are defined. In addition, some possible trends in a further globalization of modern society are analyzed, its cultural, economic, national, and political unification, as well as its consequences for Ukraine. By way of conclusion, it is stated that the positive example of several countries gives hope for a favorable relationship between the

* Doctor of Legal Sciences, Academician of the National Academy of Legal Sciences of Ukraine, Professor of the Department of Philosophy of Law and Legal Logic of the National Academy of Internal Affairs, Ukraine. ORCID ID: https://orcid.org/oooo-0002-2093-2513. Email: post@naiau.kiev.ua

** Doctor of Legal Sciences, Professor of the Department of Philosophy of Law and Legal Logic of the National Academy of Internal Affairs, Ukraine. ORCID ID: https://orcid.org/oooo-ooo2-1116-4751. Email: post@naiau.kiev.ua

*** Doctor of Philosophical Sciences, Professor of the Department of Philosophy of Law and Legal Logic of the National Academy of Internal Affairs, Ukraine. ORCID ID: https://orcid.org/oooo-0003-31462120. Email: post@naiau.kiev.ua

**** PhD in Law, Head of the Department of Philosophy of Law and Legal Logic of the National Academy of Internal Affairs, Ukraine. ORCID ID: https://orcid.org/oooo-0oo2-1911-5241. Email: post@naiau. kiev.ua

*****Ph.D. in Law, Senior Researcher at the Scientific Institute of Public Law. ORCID ID: https://orcid. org/oooo-0002-5804-0780. Email: ShkarupaK@gmail.com. 
Mychailo V. Kostytsky, Nataliia V. Kushakova-Kostytska, Oleg I. Gvozdik, Vitalii M. Kravets y Oleksandr M. Sybiha

National identity in an emerging information society: some problematic issues

development of the information society and the preservation of national cultures through the strengthening of national identity and the reactivation of spiritual values.

Keywords: society of Information; information technology; globalization; National identity; cultural identity.

\section{Identidad nacional en una sociedad de la información emergente: algunas cuestiones problemáticas}

\section{Resumen}

El objetivo del artículo es caracterizar la identidad nacional en una sociedad de la información emergente. La multidimensionalidad, las contradicciones internas y la variabilidad del fenómeno de la identidad nacional llevaron al pluralismo metodológico, la aplicación de diversos métodos y principios. Así, en el curso de la investigación se utilizaron enfoques históricos y filosóficos, dialécticos, fenomenológicos y sistémicos, métodos estructurales y funcionales. El artículo considera los problemas relacionados con el desarrollo de la sociedad de la información y la preservación de la identidad nacional, incluidas las peculiaridades de este proceso en la sociedad ucraniana moderna. Se definen los factores de desarrollo de la sociedad de la información que influyen en la conciencia nacional e individual y promueven su óptima interacción. Además, se analizan algunas posibles tendencias en una mayor globalización de la sociedad moderna, en particular, su unificación cultural, económica, nacional y política, así como sus consecuencias para Ucrania. A modo de conclusión se afirma que el ejemplo positivo de varios países da esperanzas de una relación favorable entre el desarrollo de la sociedad de la información y la preservación de las culturas nacionales mediante el fortalecimiento de la identidad nacional y la reactivación de los valores espirituales.

Palabras clave: sociedad de la información; tecnologías de la información; globalización; identidad nacional; identidad cultural.

\section{Introduction}

The end of the twentieth century was marked by the process of transition from an industrial to an information society. This primarily applies to Western Europe, the United States, Japan, China and some other technologically advanced countries and regions. The feature of this 
transition was the spiritual crisis associated with the lack of a clear ideological orientation, when the meaning of life is given to each and every one by a certain idea, justifying all the difficulties of earthly existence. Meanwhile, a characteristic is the problem of preserving national identity, which arose due to the inevitable unification of the virtual space of the Internet, the use of English as an international language (especially in the context of information technology (IT)), the emergence of certain socio-cultural "nonnational" trends. This applies to such phenomena as the formation of the so-called "mass culture", which is anti-national in nature, and its spread through the media, primarily due to the extraordinary development of IT.

The notorious consequences are the actual destruction of national cinemas, literature, television and other sources of information with the characteristics of a particular ethnic group, nationality, nation. These processes have not passed in Eastern Europe (most post-socialist countries), where the process of informatization of society is also actively taking place. In this regard, the Eastern European mentality, in particular the Ukrainian one, acquires specific features. This new mentality is formed on a new proWestern cultural basis, supplemented with such local features as emphasis on humorous and satirical genres; increased attention to the topic of death, catastrophes, violence, the end of the world; unhealthy interest in social deviations, marginals, sexual freedom and homosexuality, transsexuality; denial of scientific rationality, mysticism, sudden (mostly demonstrative) religiosity, etc. (Parkhomov et al, 2006).

\section{Literature Review}

Many foreign and domestic researchers are studying the issues related to the information society, some of them pay attention to the problem of preserving identity. Some scholars consider the destruction of national or cultural identity in connection with the globalization of the modern world. The development of the information society and the process of globalization of the economy, culture, politics, etc. are, naturally, interrelated, but they are not identical (just as the notions of national and cultural identity are not identical). So, we would like to emphasize the problem of the relationship between the information society and national identity in the Ukrainian context without dwelling in detail on the differences between globalization and informatization. In our opinion, this issue, in contrast to the study of the theory and practice of the information society, is still given quite a little attention by domestic and foreign researchers, although some aspects of it are covered by such scientists as Castells and Himanen (2003), Dyson (1998), McLuhan (2011), Meliukhin (1999), Prais (2000), Parkhomov et al, (2006), Webster (2006), Zakovorotnaia (1999) and others. 
Thus, the aim of our study is to reveal the main factors in the development of the information society, which directly affect the national and individual consciousness and contribute to their optimal interaction.

\section{Methodology}

Multidimensionality, internal contradictions, and variability of the phenomenon of national identity led to the methodological pluralism, application of various methods and principles. The use of methodological strategy, which synthesizes on the basis of complementarity historical and philosophical, dialectical, phenomenological and systemic approaches, provided understanding of the essence, structure and typology of national identity, contributed to the disclosure of its epistemological status and a wide range of theoretical and methodological modifications.

The historical and philosophical approach enabled a comprehensive study of national identity in the context of the European philosophical tradition, allowed to characterize the geo-historical dynamics of migration processes in a globalized world.

The structural and functional approach contributed to the understanding of the structural components of the phenomena of nation, national identity, and migration.

The basic principles of the methodology of work are the principles of objectivity, historicism, unity of theory and practice, historical and logical, structural, and genetic approaches.

\section{Results and Discussion}

The situation is complicated by the total imposition of trade and political advertising (again due to the IT) with a significant psychoanalytic basis (for example, advertising with elements of eroticism), technology for forming and imposing an attractive image (image-making) to serve business, politics, mass culture. As a result of these processes in our culture, such means of information and cultural exchange as literature, theater, and finally direct, live communication have been pushed to the periphery. They were replaced by cinema, television, the Internet, and mobile communications. New carriers of culture are developing extremely fast technologically, but also degrading quite quickly in terms of content. First of all, it is about emphasizing the themes of sex, violence, accumulation of material goods, consumption as a lifestyle, sex and other anti-spiritual tendencies, inherent 
in informational in form, but capitalist in content societies (BestuzhevLada, 2000).

Certainly, there are a number of positive aspects that arise due to the latest IT. These include the availability of information, the speed of its transmission, the ability to store and operate large amounts of data in a compact form, the ability to communicate regardless of distance and national borders. Unfortunately, all the high manufacturability of modern information exchange is inferior to even higher rates of moral and spiritual degradation that accompany the development of the information society. And the loss of national identity is also one of the negative consequences of informatization of society, although it can be explained by the development of the global process of political and economic globalization and cultural integration.

Let us consider the main components of this process. Firstly, there is a loss of linguistic identity: English is becoming more commonly used, even at the household level. In addition, there is such phenomenon as "Americanization" of the national language because of the dominance of American popular culture and the use of English in IT. That is, there are a huge number of words of English origin in the national language. As for the situation with the Ukrainian language, it is further complicated by its "russification" in Soviet times. Secondly, there is a loss of anthropological identity due to the assimilation and extreme spread of plastic surgery. As a result of a change in appearance, the mental state and psychology of a person also changes: a member of the Negroid race tries to be a white man, a man - to be a woman and so on.

Obviously, the national consciousness of a person also changes along with significant physiological changes because the ease of a radical change in appearance contributes to the fact that it is difficult to identify a person's nationality. This leads to "blurring" of national consciousness, reducing the sense of individual national responsibility, etc. It can also be noted that the game with the word is replaced by a game with the body, focus on bodily in general (Tulchynskyi and Uvarov, 2001). Representation of the body at the household level and in art leads to permissiveness and aesthetic development of homosexuality - both male and female. This is also facilitated by virtual technologies: IT, in particular the Internet, provides an opportunity to remain anonymous and survive in any image, even without plastic surgery. The development of means of communication, the main stages of which are language, oral language, writing, printing, artificial languages (scientific terminology), media (media), information and communication technologies (ICT) do not also contribute to the preservation of national identity.

It is obvious that scientific terminology, mass media and ICT have an international, supranational character, so their further development and dissemination lead to the erasure of national characteristics, unification 
Mychailo V. Kostytsky, Nataliia V. Kushakova-Kostytska, Oleg I. Gvozdik, Vitalii M. Kravets y Oleksandr M. Sybiha

of means of communication and information exchange. Preservation of national identity in some societies contributes to the developed religiosity of the population, the stability of social and cultural traditions. Thus, Poland has a solid foundation for maintaining national consciousness in mass religiosity or respect for Catholic traditions by the majority of the population.

As for Ukraine, the religious (Orthodox) basis, which would have contributed to the preservation of national consciousness, as a result of active ideological struggle was destroyed during the Soviet era. And no matter how much the ideology of modern Ukrainian citizens is restored by domestic ideologues, no matter how many churches are built and no matter what advertisements are made by different denominations (both Orthodox and others) Christian and other religious dogmas look outdated and unconvincing on the background of the latest information technologies, computer technology, genetic engineering, etc.

Naturally, the development of IT does not deny the belief in God as such, but certainly does not contribute to the development of traditional religious rites and the preservation of the appropriate worldview. In general, the researchers of the information society believe that the essence of the theory of the information society is reduced to the analysis of the conflict between it and cultural identity (Dyson, 1998; Castells and Himanen, 2003; Parkhomov et al, 2006). Thus, M. Castells notes that "the dominant general trend is that the progress of the global information economy causes a strong resistance, which is based on the feeling that development threatens cultural identity", (Castells and Himanen, 2003: p.35). As a result, along with the development of the information society, there is an increase in nationalism and religious fundamentalism.

The positive examples of resolving this conflict are the development of the information society in Finland and Japan. There are no nationalist movements, no religious fundamentalism, and no powerful antiglobalization movement. Thus, the Finnish model of the information society is built on the Finnish identity itself, on the policy of the "welfare state". This model mitigates the socially destructive impact of the information society and makes the success of the information society the financial basis of the welfare state.

The development of the information society in Finland has become a new project for the survival of the nation-State, which legitimizes the State as long as people can see that it contributes to the survival of Finland. An important factor in the positive development of the information society in Finland on the background of preserving national identity was the Finnish identity. It is based on ethnic homogeneity, common language, and the absence of ultranationalist sentiments. As a result of Finns' sensible and rational approach to IT, Finnish identity not only develops the information society, but is also organized on its basis. 
The entire history of the independent Finnish state is a brilliant illustration of how the information society has become and remains a project of identity creation. Information technology has become a means for Finland to show itself and the world that it is no longer poor and dependent on Sweden or Russia, and that accession to Western Europe has taken place in an ideologically neutral way by joining its technological development.

Analyzing the state of self-consciousness of modern Ukrainians, the linguistic, ideological, political situation in Ukraine, one should note a number of problematic issues related to the development of the information society and the preservation of national identity in its territory. Firstly, despite the active "ukrainization" of the population during the years of independence, there is still no linguistic identity due to the popularity of the Russian language in the country. Secondly, the only undeveloped State ideology that would unite the Ukrainian nation would become a driving force in national, social, and economic construction. Thirdly, there is the ethical issue of blurring moral and spiritual values, which has not only not been resolved, but has increased since the proclamation of Ukraine's independence.

As indicated above, Orthodox ethics, which was widespread in this area until 1917, was ousted by communist ideology. But since gaining independence in 1991, the restoration of religiosity and the spread of Orthodoxy have not become a unifying factor for Ukrainian citizens either.

It should be noted that ethics prevailing in society always becomes either a factor of social progress or a factor of its inhibition. For example, Finland has been dominated by the Protestant work ethic, which assumes the perception of work as the highest duty and the best possible fulfillment of this duty. This ethic dominates to some extent now but is gradually and quite organically transforming into another ethic - the ethics of information creation, which can be called "hacker".

The latter is primarily lying in the fact that its followers find it really interesting, stimulating and even fun. Work is self-realization for the representatives of the information age because of the use of their own creative abilities, constant self-improvement, and self-development.

We should also pay attention to another important point. There is no doubt that every phenomenon has both advantages and disadvantages. Indeed, the information society presupposes a crisis of nationalism and national identity, but is this a tragedy for modern society? Today, the degree of assimilation of different nationalities, ethnic groups and even races is such that it becomes increasingly difficult to determine the nationality of a person, especially when it comes to the so-called "developed" countries. The passports of citizens of these countries does not include the column "nationality", i.e. national identity has actually been reduced to the definition of citizenship. 
Mychailo V. Kostytsky, Nataliia V. Kushakova-Kostytska, Oleg I. Gvozdik, Vitalii M. Kravets y Oleksandr M. Sybiha

But the question arises: do American, French, Russian, Ukrainian, and other nations exist as such today? Given that national features are increasingly being erased by total assimilation, national identity is mostly determined by place of residence, which in turn is not fixed for many representatives of the above countries - they have property, economic, political and other interests in a lot of places, regardless of state borders and even less of the national identity. The development of the information society contributes to this process by providing new and very interesting meaning to total integration and assimilation.

The fact is that the ruling class of the information society is intellectuals, and the main value of the information age is knowledge and their own abilities. Thus, a person's belonging to a certain nation ("I am an American", "I am a Russian", "I am a Ukrainian", etc.), certain social or oligarchic group ("I am the son of a president / businessman / scientist", etc.) is gradually losing its relevance, because a person's value is determined not by nationality, social status, financial and other material capabilities, but his (her) creativity, intelligence and level of knowledge, access to information and the ability to operate it. This in turn creates a tendency to total unification in various senses: linguistic, national, cultural, economic, etc., which leads to the selection of one language as the dominant and most used (obviously today it is English), erasing national characteristics and features, developing single ethics and principles of co-existence regardless of official State borders, current legislation, religious guidelines, local traditions (Zakovorotnaia, 1999). Not everyone will agree that this tendency inherent in the information society is positive, but, in our opinion, it is a significant step forward compared to the existing consumer society, which is characterized primarily by the total dictate of money transformed into the highest value and meaning of existence.

\section{Conclusion}

The problem of identity in theoretical and practical aspects is one of the fundamental one for the socio-philosophical sphere of knowledge. The social nature of an individual implies that he (she) seeks to be included in the community, society and at the same time - to be separated from them as a personality. Identity is the awareness, feeling, experience of belonging to various social communities, such as family, professional group, class, territorial community, ethnic group, nation, social movement, State, humanity in general.

One of the leading places in the set of identities is occupied by national identity. The difficulties in defining national identity arise not only because of the ambiguity of the concept of "identity", but also due to its synthetic 
nature, which makes it the subject of interdisciplinary research. This leads to the accumulation of a significant number of definitions. The lack of a holistic definition and clear conceptualization of national identity prevent us from establishing the criteria and conditions for their application. Besides, many researchers use the term "identity", to denote its varieties as something a priori clear that does not require any definitions. However, despite the desire of some authors to abandon the use of the category of national identity, it remains the subject of intensive research.

The problem of national identity first became the subject of scientific discourse in the $19^{\text {th }}$ century and becomes more and more relevant under the globalization processes.

Summing up, we can say that, despite a number of serious contradictions and problems caused by the informatization of most societies, in particular, Ukrainian one, the scenario of technological civilization continues to unfold. At the same time, the integration of national cultures into the world's multicultural space is constantly growing, and national identity is under threat of destruction. But the positive example of a number of countries gives hope for some favorable relationship between the development of the information society and the preservation of national cultures by raising national identity, developing the right State ideology, the revival of spiritual values.

\section{Bibliographic References}

BESTUZHEV-LADA, Yhor. 2000. The 21st century is ahead: prospects, forecasts, futurologists. Anthology of modern classical prognostics. 1952 - 1999. Academia, 2000. Moscow, Russia.

CASTELLS, Manuel; HIMANEN, Pekka. 2003. The Information Society and the Welfare State: The Finnish Model, 1st edition. Oxford University Press. Oxford, United Kingdom.

DYSON, Esther. 1998. Release 2.1: A Design for Living in the Digital Age, 1st edition. Crown Business. New York, United States.

McLUHAN, Marshall. 2011. The Gutenberg Galaxy. University of Toronto Press, Scholarly Publishing Division. Toronto, Canada.

MELIUKHIN, Ihor. 1999. Information Society: Origins, Problems, Development Trends. Publishing House of Moscow University. Moskow, Russian. 
Mychailo V. Kostytsky, Nataliia V. Kushakova-Kostytska, Oleg I. Gvozdik, Vitalii M. Kravets y Oleksandr M. Sybiha

94 National identity in an emerging information society: some problematic issues

PARKHOMOV, Yurii; PAVLENKO, Yurii; SHEVCHUK, Oleh. 2006. Civilizational structure of the modern world. In: Global transformations of our time. Vol. 1. Naukova dumka. Kyiv, Ukraine.

PRAIS, Monro. 2000. Television, telecommunications and transition: law, society and national identity. Publishing House of Moscow University. Moscow, Russia.

TULCHYNSKYI, Hryhorii; UVAROV, Mikhail (eds). 2001. Metaphysical perspective: classical and non-classical metaphysics at the turn of the century. Aleteiia. Saint-Petersburg, Russia.

WEBSTER, Frank. 2006. Theories of Information Society (International Library of Sociology), 1st Edition. Routledge. London, United Kingdom.

ZAKOVOROTNAIA, Marharyta. 1999. Human identity. Socio-philosophical aspects. Publishing house of the North Caucasus Scientific Center of Higher Education. Rostov on Don, Russia. 


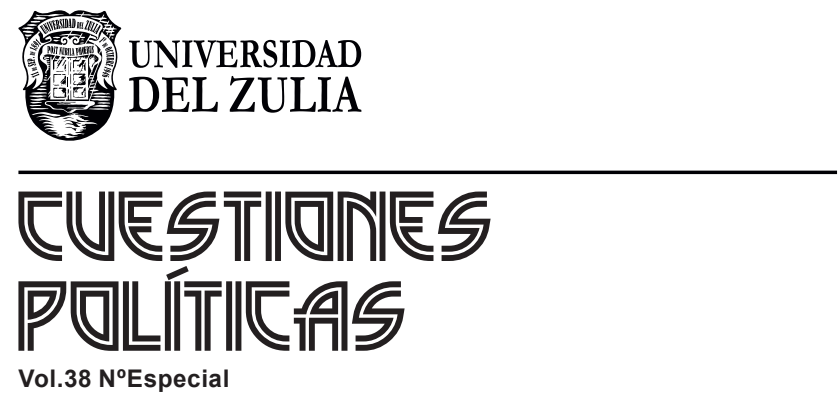

www.luz.edu.ve 